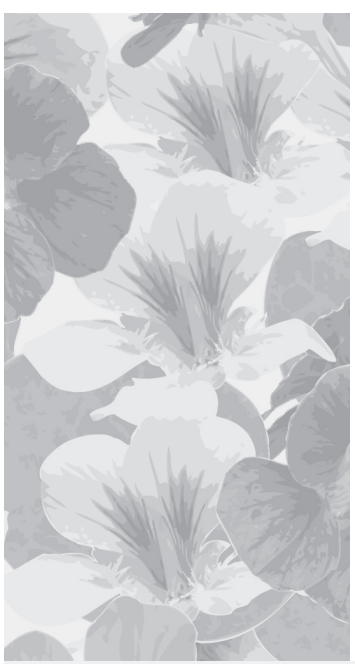

\title{
Regulacje prawne zawodu kosmetologa: Więcej pytań niż odpowiedzi
}

\section{Legal regulations for the profession of cosmetologist: More questions than answers}

\author{
Olga Dębska1, Sławomir Dębski², Radosław Śpiewak
}

${ }^{1}$ Zakład Dermatologii Doświadczalnej i Kosmetologii, Wydział Farmaceutyczny, Uniwersytet Jagielloński Collegium Medicum, Kraków

${ }^{2}$ Kancelaria Notarialna, Włoszczowa

Estetol Med Kosmetol 2012; 2(3): 72-76

DOI: http://dx.doi.org/10.14320/EMK.2012.015

\section{Streszczenie}

Przy podejmowaniu problematyki regulacji prawnych zawodu kosmetologa istotne są stale rosnące oczekiwania klientów (pacjentów) w odniesieniu do kompetencji i przygotowania zawodowego kosmetologów. Celem pracy było opisanie problemów związanych z brakiem uregulowań prawnych wykonywania zawodu kosmetologa w obowiązującym w Polsce systemie prawnym, a także zaproponowanie w jakim kierunku powinny zmierzać działania w tym zakresie, z jakich osiągnięć i doświadczeń można korzystać oraz jakie aspekty należy uwzględnić. Materiat i metody: Przeanalizowano status prawny (ustawy oraz rozporządzenia) dotyczące wykonywania zawodu kosmetologa w Polsce. Wyniki: Aktualnie nie ma regulacji prawnych jasno określających status i reguły wykonywania zawodu kosmetologa. Potwierdzenie statusu zawodu kosmetologa jako zawodu medycznego i objęcie go obowiązującą Ustawą o niektórych zawodach medycznych wydaje się prostsze, szybsze i w sposób pewniejszy gwarantujące osiągnięcie zamierzonego celu. W przypadku przyjęcia koncepcji, że zawód kosmetologa nie jest zawodem medycznym, jedyną właściwą drogą uregulowania omawianej materii byłoby podjęcie prac nad stworzeniem odrębnej ustawy. Tworzenie od podstaw odrębnej ustawy dawałoby szansę na pełniejsze i kompleksowe uregulowanie zasad wykonywania zawodu kosmetologa, z drugiej jednak strony byłoby drogą dłuższą, wymagającą znacznie większych wysitków przy braku gwarancji osiągnięcia zamierzonego celu. Wnioski: Kosmetolog w ramach pracy wykonuje zabiegi na ludziach w związku z tym stworzenie prawnych ram funkcjonowania tego zawodu leży w żywotnym interesie spotecznym. W obecnym porządku prawnym zawód kosmetologa nie jest uregulowany w sposób gwarantujący bezpieczeństwo indywidualnych klientów (pacjentów), ani osób praktykujących ten zawód. Konieczne są dalsze badania i analizy, które dostarczą danych niezbędnych dla konstruktywnej dyskusji nad definicją zawodu kosmetologa oraz stworzenia niezbędnych ram prawnych jego funkcjonowania.

Stowa kluczowe: zawód kosmetologa, status prawny, kompetencje, obowiązki, regulacje prawne

\section{Abstract}

While discussing the problems of legal regulations governing the profession of cosmetologist, one has to consider the ever-increasing expectations of the customers (patients) with regard to professional skills and competences of cosmetologists. The aim of this study was to describe the current problems resulting from the lack of regulation of the cosmetologist's profession in the Polish legal system, as well as to propose the possible direction in which further initiatives in this area should be aimed, and from which achievements and experience can be learnt, and what aspects should be taken into account in the first instance. Material and methods: The legal Polish regulations (Acts, directives) have been reviewed that directly or indirectly relate to the execution of the cosmetologist's profession. Results: At present, there is still a lack of legal regulations which clearly and unequivocally set the professional rules for cosmetologists. The acceptance of the status of the profession of cosmetologist as one of the medical professions and placing it within the jurisdiction of the Act of auxiliary medical professions seems a more simple, fast and reliable way of achieving the intended goal. In case of deeming the profession of cosmetologist as a non-medical profession, passing a dedicated legal Act into the body of legislation would be necessary. Although the latter option would provide an opportunity for creating a regulation better fitting to the profession of cosmetologist, it would also require more time and effort without any guarantee of achieving the intended objective. Conclusion: The professional activities of a cosmetologist include procedures carried out on live people; therefore, strict rules for the execution of duties within this scope should serve the vital public interest. At present, however, the profession of cosmetologist is not regulated in any way that would ensure the safety of both the individual customer (patient) and the cosmetologist. There is a need for further research and analysis to provide facts that would facilitate a constructive discussion on the definition of the profession of cosmetologist, as well as the creation of the necessary legal regulations.

Keywords: cosmetologist, legal status, competence, obligations, legal regulations

Copyright @ 2012 the Authors (text) and Radosław Śpiewak (layout \& journal compilation). All rights reserved.

Mimo podejmowanych prób w tym zakresie, w Polsce nadal brakuje uregulowań prawnych, które w jasny i nie budzący wątpliwości sposób określałyby zasady wykonywania usług przez kosmetologów. Dzieje się tak mimo dynamicznego rozwoju kosmetologii jako dziedziny nauki i stale rosnącego zainteresowania studiowaniem na tym kierunku [1]. Odpowiedzią na ten popyt jest tworzenie warunków do nauki na poziomie studiów wyższych na kierunku Kosmetologia w renomowanych uczelniach medycznych (m. in. Uniwersytet Jagielloński, Uniwersytet Medyczny w Łodzi, Uniwersytet Medyczny w Poznaniu). Brak jednoznacznie określonych ram działania w przyszłym zawodzie jest jedną $\mathrm{z}$ istotnych przyczyn niepokoju studentów kosmetologii i trudno- 
ści w opracowaniu programu zapewniającego studentom wykształcenie zgodne z przyszłymi obowiązkami i uprawnieniami [2].

\section{Cel pracy}

Celem pracy było opisanie problemów związanych z niedostatkiem uregulowań wykonywania zawodu kosmetologa w obowiązującym w Polsce systemie prawnym, a także zaproponowanie, w jakim kierunku powinny zmierzać działania w tym zakresie, z jakich osiągnięć i doświadczeń można korzystać oraz jakie dodatkowe aspekty należy uwzględnić. Przy podejmowaniu tej problematyki istotne są stale rosnące oczekiwania klientów (pacjentów) w odniesieniu do kompetencji i przygotowania zawodowego kosmetologów.

\section{Materiat i metody}

Przeanalizowano status prawny (ustawy oraz rozporządzenia) dotyczące bezpośrednio lub pośrednio wykonywania zawodu kosmetologa w Polsce.

\section{Prawo polskie a regulacje europejskie}

Przy rozważaniu zakresu i sposobu regulacji działalności zawodowej kosmetologa w Polsce niezbędne jest uwzględnienie systemu prawa polskiego, jednak warto spojrzeć na rozwiązania, dorobek i doświadczenia innych państw, w szczególności europejskich. Kluczowe znaczenie ma ustalenie, czy dyrektywy i przepisy obowiązujące w Unii Europejskiej regulują tę problematykę i w jakim zakresie muszą być one inkorporowane do prawa polskiego. W przypadku braku takich regulacji na poziomie unijnym, rozważenia wymaga, czy korzystne byłoby zainteresowanie tą problematyką instytucji unijnych w celu stworzenia takich dyrektyw. Jest to istotne nie tylko wobec konieczności wdrażania norm i dyrektyw unijnych (chociażby celem uniknięcia narażenia państwa polskiego na ewentualne negatywne skutki zaniechań), ale także po to by nie tworzyć w tej dziedzinie standardów niższych niż obowiązujące w innych krajach.

\section{Nowe regulacje a prawo wewnętrzne}

Konstruowanie norm prawnych w omawianym zakresie powinna cechować szczególna staranność, tak by ich stworzenie nie prowadziło do sprzeczności z podstawowymi zasadami konstytucyjnymi (np. w zakresie wolności wyboru zawodu lub prowadzenia działalności gospodarczej), a także uregulowaniami zawartymi w przepisach niższej rangi (ustawy, rozporządzenia itd.). Istotne przy tym jest także znalezienie odpowiedzi na pytanie, czy przy poszukiwaniu optymalnego rozwiązania problemu statusu zawodu kosmetologa podążać należy ku stworzeniu nowej, odrębnej ustawy statu- ującej ten zawód, czy też może dokonać zmiany obowiązującego stanu prawnego, w szczególności Ustawy o niektórych zawodach medycznych.

\section{Dotychczasowe próby regulacji zawodu}

Podejmując próbę zainteresowania ustawodawczych i wykonawczych organów państwa kwestią uregulowania statusu zawodowego kosmetologa nie można nie wspomnieć o najważniejszej dotychczas inicjatywie, czyli podjętej w 2005 roku próbie stworzenia norm prawnych dla wybranych zawodów medycznych, w tym zasad uzyskiwania tytułu specjalisty w nieuregulowanych wcześniej dziedzinach ochrony zdrowia. Efektem tych prac był projekt ustawy o niektórych zawodach medycznych zawierający rozwiązania dotyczące zawodu kosmetologa [3], przekazany do uzgodnień zewnętrznych, czyli zaopiniowania przez zainteresowane nimi grupy zawodowe. Działania te zostały zaniechane po wygaśnięciu kadencji Sejmu pod koniec 2011 roku, na skutek braku zainteresowania tą inicjatywą ze strony nowego Ministra Zdrowia i Opieki Społecznej (tabela 1). W przypadku nowych inicjatyw w tym zakresie, istotne byłoby ustalenie motywów niepodjęcia dalszych prac nad omawianym projektem ustawy oraz uzyskanie deklaracji na temat przyszłych planów Ministerstwa Zdrowia i Opieki Społecznej w tym zakresie. We wspomnianym projekcie ustawy o niektórych zawodach medycznych, w przepisie art. 1 ust. 3 proponowano: „ilekroć w ustawie jest mowa o zawodzie medycznym należy przez to rozumieć zawody wymienione w ust. 1", co oznaczało, że tylko zawody wymienione w projektowanej ustawie miały mieć status zawodów medycznych. Innymi słowy inne zawody, nawet te związane z ochroną zdrowia lecz nie wymienione w projektowanej ustawie nie byłyby uznawane za zawody medyczne. $\mathrm{Z}$ kolei w art. 2 ust. 1 projektu ustawy proponowano by ,wykonywanie zawodu medycznego polegało na realizacji właściwych dla danego zawodu medycznego zadań służących profilaktyce, zachowaniu, ratowaniu, przywracaniu i poprawie zdrowia oraz innych zadań związanych z procesem leczenia, zwanych dalej »zadaniami zawodowymi«". Tę szeroką definicję można interpretować jako definicję otwartą, która swoim zakresem obejmować miała nie tylko zawody wskazane w tej ustawie. Za taką interpretacją przemawiałby również fakt, że w aktualnie obowiązującym Rozporządzeniu Ministra Pracy i Polityki Społecznej zawód kosmetologa jest wymieniany w kategorii ,specjaliści ochrony zdrowia (z wyjątkiem pielęgniarek i położnych) gdzie indziej niesklasyfikowani”[4].

\section{Perspektywy na przysztość}

Wspomniana inicjatywa prawnego uregulowania zawodu kosmetologa stanowi, jak się wydaje, dobry punkt wyjścia do dalszych prac ustawodawczych. 
Zawarte w niej propozycje dotyczące zakresu uprawnień zawodowych wymaganych od osób wykonujących zawód w ramach ochrony zdrowia precyzowały jednak wyłącznie zakres czynności zawodowych wykonywanych przez kosmetologa, pomijając pozostałe aspekty jego działalności, takie jak profilaktyka i edukacja zdrowotna. Dalsze prace będą wymagały zatem rozstrzygnięcia zasadniczej kwestii, czy zawód kosmetologa winien być sytuowany wśród zawodów medycznych. Rozstrzygnięcie takie wymagałoby stworzenia nieobecnych dotąd w systemie prawa polskiego precyzyjnych definicji zawodu medycznego oraz osoby wykonującej zawód medyczny. W przyszłych inicjatywach należy dążyć do uniknięcia nieścisłości, czy wręcz niekonsekwencji ustawodawcy polskiego, który w nieobowiązującym już przepisie art. 18d ust. 1 pkt. 1 ustawy z dnia 30 sierpnia 1991 roku o zakładach opieki zdrowotnej, stwierdzał, iż: ,za osobę wykonującą zawód medyczny uważa się osobę, która na podstawie odrębnych przepisów uprawniona jest do udzielania świadczeń zdrowotnych oraz osobę legitymującą się nabyciem fachowych kwalifikacji do udzielania świadczeń zdrowotnych w określonym zakresie lub określonej dziedzinie medycyny" [5]. Na tej podstawie można było wnioskować, że wykonywanie zawodu medycznego polega wyłącznie na udzielaniu świadczeń zdrowotnych. Natomiast w myśl art. 3 ustawy o zakładach opieki zdrowotnej świadczeniem zdrowotnym są działania służące zachowaniu, ratowaniu, przywracaniu i poprawie zdrowia oraz inne działania medyczne wynikające $z$ procesu leczenia lub przepisów odrębnych regulujących zasady ich wykonywania. Definicja zawodu medycznego z art. 18 d ust. 1 pkt. 1 ustawy z dnia 30 sierpnia 1991 roku o zakładach opieki zdrowotnej, mimo niezgodności z definicją z art. 3 ustawy o zakładach opieki zdrowotnej, została w formie niezmienionej zachowana w aktualnie obowiązującej ustawie o działalności leczniczej z dnia 15 kwietnia 2011 r. [6].

Dla określenia miejsca i roli zawodu kosmetologa szczególnie istotna będzie analiza obszaru jego działalności, określenie zasad wykonywania zawodu i zakresu wykonywanych czynności, sprecyzowanie warunków dopuszczenia do wykonywania zawodu, ustalenie wymaganego wykształcenia teoretycznego i praktycznego, zdefiniowanie obowiązków wobec zdrowia publicznego (profilaktyka i edukacja zdrowotna), a także określenie zasad ograniczenia bądź wznowienia prawa wykonywania zawodu [7,8]. W rozważaniach nad uregulowaniem ram prawnych zawodu kosmetologa nie można też pominąć kwestii powołania do życia samorządu zawodowego, którego roli i znaczenia nie sposób przecenić, a którego działanie sprawdziło się w przypadku wielu innych zawodów, także medycznych.
Tabela 1. Losy projektu Ustawy o niektórych zawodach medycznych i zasadach uzyskiwania tytutu specjalisty w innych dziedzinach zastosowania w ochronie zdrowia

\begin{tabular}{c|l} 
Data & \multicolumn{1}{c}{ Etap prac legislacyjnych } \\
\hline 26.07 .2005 & $\begin{array}{l}\text { przekazanie projektu ustawy do uzgodnień zewnętrznych - grup } \\
\text { zawodowych }\end{array}$ \\
\hline 27.10 .2006 & przekazanie projektu do Komitetu Rady Ministrów \\
\hline 4.12 .2006 & przekazanie projektu do weryfikacji prawnej - Komisji Prawniczej \\
\hline 19.01 .2007 & tekst skierowany pod obrady Rady Ministrów \\
\hline 14.03 .2007 & skierowanie projektu do Sejmu \\
\hline 11.08 .2008 & przekazanie projektu do uzgodnień zewnętrznych - grup zawodowych \\
\hline 09.02 .2009 & przekazanie projektu do Komitetu Rady Ministrów \\
\hline 29.10 .2009 & $\begin{array}{l}\text { projekt ustawy przyjęty przez Kierownictwo Ministra Zdrowia po } \\
\text { uzgodnieniach resortowych }\end{array}$ \\
\hline 31.05 .2010 & projekt skierowany pod obrady Komitetu Stałego Rady Ministrów \\
\hline 07.09 .2010 & wersja projektu przekazana pod obrady Rady Ministrów \\
\hline 18.11 .2011 & zmiana Ministra Zdrowia - wstrzymanie prac nad projektem ustawy
\end{tabular}

\section{Wymagania w zakresie kwalifikacji zawodowych i kontrola wykonywania zawodu}

Kształcenie kosmetologów na poziomie studiów licencjackich i magisterskich, zarówno w szkołach prywatnych jak i państwowych jest realizowane zgodnie ze standardami obowiązującymi dla kierunków medycznych. Określenie wymagań formalnych w zakresie wykształcenia teoretycznego i praktycznych umiejętności będzie wymagać rozstrzygnięcia, czy osoba podejmująca pracę w zawodzie kosmetologa powinna zdawać egzamin państwowy w celu uzyskania prawa wykonywania zawodu określającego jednoznacznie zakres jej praw i obowiązków. Nie jest to bez znaczenia, chociażby w kontekście istnienia takiego obowiązku wobec przyszłych kosmetyczek (tytuł zawodowy ,technik usług kosmetycznych”). Pożądane będzie również określenie zasad prowadzenia i dokumentowania obowiązkowego podyplomowego doskonalenia zawodowego oraz wprowadzenia specjalizacji dla kosmetologów. Doprecyzowanie zasad wykonywania zawodu da możliwość weryfikacji kompetencji i przydatności osób podejmujących pracę w charakterze kosmetologa, jak również oceny ich pracy. Możliwość weryfikacji kwalifikacji danej osoby zapewnić mógłby ogólnodostępny rejestr zawodowy. Jednoznaczne zdefiniowanie zakresu działań kosmetologa stworzyłoby także możliwość właściwej kontroli oraz egzekwowania standardów zawodowych i etycznych, w tym również pod sankcją pozbawienia prawa wykonywania zawodu. Niewątpliwie zapewniłoby to utrzymanie wysokiego standardu świadczonych usług.

\section{Odpowiedzialność zawodowa i odszkodowawcza}

Zasadnicza nie tylko dla kosmetologów, ale także dla osób korzystających z ich usług będzie kwestia odpowiedzialności zawodowej za wykonywane czynności. Oczywistą odpowiedzialność kontraktową i deliktową 
należałoby uzupełnić o ustawowo uregulowaną odpowiedzialność dyscyplinarną (sądownictwo dyscyplinarne w ramach samorządu zawodowego kosmetologów, uzupełnione o osoby z innych zawodów np. medycznych) oraz jasno zdefiniowaną odpowiedzialność karną za naruszenie nietykalności cielesnej lub uszkodzenie ciała poprzez przerwanie ciągłości tkanki. Regulacji wymagają ponadto kwestie zgody pacjenta i związanego z tym wyłączenia odpowiedzialności. Szeroki zakres usług wykonywanych przez kosmetologa, jego ingerencja w istotne dobra usługobiorców (pacjentów) wymaga rozważenia wprowadzenia obowiązkowego, a nie jak dotychczas fakultatywnego, ubezpieczenia od odpowiedzialności cywilnej z jednoczesnym określeniem minimalnej kwoty tego ubezpieczenia, gwarantującej skuteczne dochodzenie odszkodowań ze strony ewentualnych poszkodowanych.

\section{Opodatkowanie działalności i możliwość reklamy}

Istotne jest również rozważenie i zaproponowanie takich zmian w formach opodatkowania działalności prowadzonej przez kosmetologa, aby mogła być ona wykonywana na zasadach obowiązujących w zawodach pokrewnych. W obecnym systemie podatkowym trudno doszukać się logiki: usługi lekarskie wykonywane w ramach medycyny naprawczej i profilaktycznej zwolnione są z podatku VAT, usługi medycyny estetycznej oraz kosmetyczne opodatkowane są stawką podstawową wynoszącą 23\%, zaś na przykład usługi fryzjerskie opodatkowanie są preferencyjną stawką VAT w wysokości 8\% [9]. Należy także zastanowić się nad możliwością reklamy gabinetów kosmetycznych [10]. Gdyby zawód kosmetologa został włączony do kategorii zawodów medycznych, nie można byłoby pominąć faktu, iż obecnie gabinety lekarskie nie mogą reklamować swoich usług, ponieważ są one ograniczone Ustawą o zawodach lekarza i lekarza dentysty, Ustawą o zakładach opieki zdrowotnej, Ustawą o izbach lekarskich, Uchwałą Naczelnej Rady Lekarskiej oraz Kodeksem etyki lekarskiej [11-14].

\section{Wnioski}

Prawne uregulowanie statusu zawodu kosmetologa przyniesie korzyści nie tylko osobom wykonującym ten zawód, lecz przede wszystkim osobom korzystającym z ich usług. Spowoduje to niewątpliwie podniesienie prestiżu zawodu, między innymi dzięki określeniu zasad uzyskiwania oraz możliwości posługiwania się tytułem zawodowym, który gwarantowałby posiadanie wymaganych kwalifikacji i umiejętności zawodowych. Objęcie zawodu kosmetologa (jako zawodu medycznego) istniejącą ustawą o niektórych zawodach medycznych wydaje się prostszą i szybszą drogą do zamierzonego celu. Tworzenie od podstaw odrębnej ustawy, która niewątpliwie bardziej szczegółowo regulowałaby wykonywanie zawodu kosmetologa jest drogą dłuższą (także ze względów legislacyjnych) i wymagającą znacznie większego nakładu pracy (konieczność opracowania i wdrożenia wielu szczegółowych rozwiązań). W przypadku przyjęcia koncepcji, że zawód kosmetologa nie jest zawodem medycznym, jedyną właściwą drogą uregulowania omawianej materii byłoby podjęcie prac nad stworzeniem odrębnej ustawy, z wykorzystaniem dotychczasowych doświadczeń i ominięciem dotychczasowych błędów. W tym celu konieczne są dalsze badania i analizy, które dostarczą danych niezbędnych dla konstruktywnej dyskusji nad definicją zawodu kosmetologa oraz stworzenia niezbędnych ram prawnych jego funkcjonowania.

\section{Piśmiennictwo}

1. Arct J: Kształcenie kosmetologiczne. Estetol Med Kosmetol 2012;2(1):7-10.

2. Dębska-Ratuszniak O, Plichta D, Śpiewak R: Motywacje, aspiracje edukacyjne i zawodowe oraz poziom kompetencji słuchaczy studiów magisterskich na kierunku kosmetologia Uniwersytetu Jagiellońskiego. Estetol Med Kosmetol 2012;2(1):28-32.

3. Projekt Ustawy o niektórych zawodach medycznych i zasadach uzyskiwania tytułu specjalisty w innych dziedzinach mających zastosowanie w ochronie zdrowia, 2009.

4. Rozporządzenie Ministra Pracy i Polityki Społecznej z dnia 27.04.2010 r. w sprawie klasyfikacji zawodów i specjalności na potrzeby rynku pracy oraz zakresu jej stosowania, Dziennik Ustaw z 2010 r. nr 82 poz.537 oraz z 2012 r. poz. 1268.

5. Ustawa z dnia 30 sierpnia 1991 r. o zakładach opieki zdrowotnej. Dziennik Ustaw z 1991 nr 91 poz. 408 z późn. $z$ m.

6. Ustawa z dnia 15 kwietnia 2011 r. o działalności leczniczej. Dziennik Ustaw z 2011 nr 112 poz. 654 z późn. $z m$.

7. Rozporządzenie Ministra Nauki i Szkolnictwa Wyższego z dnia 12 lipca 2007 r. Załącznik nr 58 Standardy kształcenia dla kierunku studiów: Kosmetologia. Dziennik Ustaw z 2007 r. nr 164, poz. 1166.

8. Plichta D, Śpiewak R: Edukacja zdrowotna i promocja zdrowia w gabinecie kosmetologicznym. Estetol Med Kosmetol 2012;2(2):44-9.

9. Ustawa $z$ dnia 11.03.2004 r. o podatku od towarów i usług, Dziennik Ustaw z 2011 r. nr 177, poz. 1054.

10. Zabiegała A, Śpiewak R: Marketing internetowy usług z zakresu medycyny estetycznej, dermatologii estetycznej oraz chirurgii estetycznej. Estetol Med Kosmetol 2012;2(1):24-7.

11. Ustawa o zawodach lekarza i lekarza dentysty $z$ dnia 5 grudnia 1996 r. z późn. zm, Dziennik Ustaw z 2011; nr 277: poz. 1634 .

12. Uchwała Nr 18/98/III Naczelnej Rady Lekarskiej z dnia 16 grudnia 2011 r. w sprawie szczegółowych zasad podawania do publicznej wiadomości informacji o udzielaniu przez lekarzy i lekarzy-dentystów świadczeń zdrowotnych. 
13. Ustawa o izbach lekarskich z dnia 2 grudnia 2009 r. Dziennik Ustaw z 2009; nr 219: poz.1708

14. Naczelna Rada Lekarska: Kodeks etyki lekarskiej z dnia 2 stycznia 2004 r.: art. 63.

\section{Finansowanie i konflikt interesów}

Przedstawione badania i przygotowanie niniejszej publikacji zostało w całości sfinansowane z własnych środków autorów. Autorzy deklarują niewystępowanie konfliktu interesów w odniesieniu do treści zawartych w niniejszej pracy.

\section{Adres do korespondencji}

dr hab. med. Radosław Śpiewak, profesor UJ Zakład Dermatologii Doświadczalnej i Kosmetologii Wydział Farmaceutyczny UJ ul. Medyczna 9, 30-688 Kraków Tel.: 1262058 30, Fax: 126205645

E-mail: spiewak.eu@gmail.com

Data złożenia: 12.06.2012

Data akceptacji: 22.07.2012 